\title{
COLOUR SYMBOLS IN MARI SONGS
}

\author{
Natalia Glukhova
}

\begin{abstract}
This article presents a system of colour symbols in Mari folk songs based on the results of a multifold investigation. The research was carried out with the help of a complex technique applied to 2100 songs from different song collections. Mari colour symbols have never before been the object of research. The process of investigation included several steps. The most important of these was the semantic analysis that helped to discern 2000 mentions of four main spectre colours as well as white, black, silver, and golden. Quantitative data evaluation singled out a dominant group by a dichotomous method, applying the principle of simple majority employed in mathematical statistics. The same technique divided the other colour symbols into complementary, auxiliary, and insignificant groups. The results of an investigation into ethnic symbology are also shown graphically. The main reconstructed meanings of colour in the analysed songs denote such emotions as joy, wonder, astonishment, grief, melancholy, some aesthetic ideals, ethical vices, as well as people's character and appearance.
\end{abstract}

Keywords: auxiliary, complementary, complex technique, dominant, folk songs, insignificant groups, ranking/rating, semantic analysis, symbol, systems theory

\section{INTRODUCTION}

\section{Symbol}

Being one of the fundamental concepts of philosophy, aesthetics, and arts, symbol has a long history of research, interpretation, and comprehension. Among works dedicated to symbol studies Aleksei Losev's monographs and articles were the source of inspiration for home scholars and were considered to be of utmost importance for symbology. In one of his monographs the author offers a logical analysis of nine moments that constitute symbol, as well as classification of symbol types to which he refers as scientific, philosophical, mythological, religious, ideological, artistic, determinative, and technical symbols (Losev 1995 [1976]: 264-274).

Symbol is compared to such art categories as 'sign', 'allegory', 'personification', 'artistic image', 'type', 'metaphor', and 'myth'.

Yuri Lotman in his works on symbol shows that symbol represents a certain text both on the plane of expression and on the plane of content, i.e. has 
a single meaning and a distinctly expressed border allowing distinguishing it from a surrounding semiotic context (Lotman 1992: 192). In this case a symbol is a kind of semiotic condenser, playing the role of a mediator between the synchrony of the text and cultural memory (Lotman 2000: 249). Yuri Lotman's valuable observations on symbols are also concerned with its archaic character and the fact that symbols represent one of the most stable elements of the cultural continuum.

Generalisation of different theories on the correlation of sign and symbol, the interpretation of symbol in art, literature studies, philosophy, and in different schools of semiotics is presented in the publications of the last decade. Thus, the history of a theoretical comprehension of symbol in philosophy, aesthetics, philology, and psychoanalysis is described in Sergei Averintsev's works, where the author pays much attention to the understanding of symbol in different schools of thought in the 20th century (Averintsev 2001: 155-161).

A concise overview of foreign scholars' theories on the nature of symbols used in various cultures, rituals, and everyday life is offered in the article written by Edit Turner in Folklore: Encyclopedia of Beliefs, Customs, Tales, Music, and Art (Turner 1997: 25-29). She briefly mentions Émile Durkheim's works and his school in France at the beginning of the 20th century, discusses Edward Sapir's works who showed the complexity of symbol as a multivalent phenomenon having many meanings, and points at Victor Turner's research. She also discusses the understanding of symbols by Sigmund Freud, Carl Gustav Jung, Raymond Firth, Claude Lévi-Strauss, Lindsey K. Girtz, and Don Handelman (Turner 1997: 28).

Philologists studying the folklore of Finno-Ugric peoples usually refer to the works of Russian scholars who studied traditions and customs of Slavic ethnoses. They are Aleksandr Veselovskii, Aleksandr Potebnia, Boris Sokolov, and Yuri Sokolov. In their investigations there are explanations of psychological origin of peoples' symbolics (Veselovskii 1940: 107-117), the meanings of separate symbolic images in folk poetry (Potebnia 1989: 285-378), as well as a social aspect of symbols in people's lyrics (Sokolov 1941: 125-456).

Taking into consideration the works on symbol I use a working definition in this article. Symbol is an object/phenomenon of extra-linguistic reality denoted by a lexeme which is the first member of a two-member parallel construction in the song without a second part of the parallel. Symbol is regarded, considering its denomination, the number of its meanings, and the probability of its usage that testifies to its importance in the ethnic folk song genre. 


\section{Colour symbolism}

Universal symbols among all nations are names of the colours of natural objects. Scholars, artists, poets, composers, and writers have provided various classifications of colours, and investigated colour meanings as well as their emotional impact on people. There is extensive literature on the subject, which can be recommended to the readers (see: Vezhbitskaia 1996: 231-291; Goethe 1957: 300-340; Deribere 1964; Frumkina 1984; Yanshin 2006: 18-91; Berlin \& Kay 1991 [1969]; Uusküla \& Sutrop 2007: 102-123; Uusküla 2007: 367-397; Davies \& Corbett 1994: 65-89; Uliashev 1999; Ryabina 2011).

In the analysed material of 2100 Mari folk songs there are 2000 mentions of four main colours of the spectre, as well as white and black. Dominant colours are white, black, and silver; they constitute $59.3 \%$ of all colour mentions in the investigated songs. Yellow, red, and green compose the next group by their frequency of mention, and blue, golden, brown, and grey complete the colour palette of the analysed Mari songs.

In connection with this fact it is quite appropriate to cite O. Spengler's words on colour symbols of different ethnoses, which testify to some coincidence of semantics in Mari songs with the interpretation of colours in ancient cultures. He argued that yellow and red are ancient paints of matter, closeness, popular colours, colours of people's masses. Blue and green are colours of loneliness and solitude, care, ties of a present moment with the past and future, destiny, colours of fate (Spengler 2000: 360-374).

In P. Yanshin's Psikhosemantika tsveta (Psychosemantics of colour) there is a part on the evolution of colour thesaurus and enrichment of colour archetype in different languages and cultures. Referring to Berlin and Kay's work (1991 [1969]) the author points out the presence of primordial simplest colour vocabulary containing only two designations - for black (dark) and white (light). Later on red is added to black and white, and in this case yellow, orange, and brown might be included in the group of 'red'. White, black, and red are considered the earliest colour designations among many peoples. Blue, yellow, and green followed them (Yanshin 2006: 162-170).

The combination of colours and their meanings in the cultures of FinnoUgric peoples coincides in some way and differs from semantics described on the materials of other ethnoses. This will be demonstrated on the examples of Mari songs. 


\section{METHODOLOGICAL FRAMEWORK}

The research combines methods and techniques of semantic analysis to which I refer componential and contextual types of analyses and systems theory. Systems theory, in turn, involves factor and statistical analysis, including the principle of a simple majority of a dichotomous method. Thus the investigation into colour symbolism consists of several stages worked out by Vladimir Glukhov, which were applied to different Mari folklore genres.

The algorithm of the research includes the following steps:

1. The process of reading texts with the aim of discerning symbols (referred to with the unifying term 'factor') after applying the componential and contextual types of text and lexeme analysis;

2. The compilation of the list of factors (symbols);

3. The distribution of the texts according to the factors;

4. The estimation of factor incidence and calculation of the probability of factor usage (the preparation of tables);

5. The ranking of factors in the descending order of probability (the preparation of probability distribution diagrams);

6. The singling out of dominant, complementary, auxiliary, and insignificant factors by a dichotomous method, applying the principle of simple majority employed in mathematical statistics (Glukhov \& Glukhova 2013: 399-412).

Thus at the beginning of the research texts of songs were read and analysed with the aim of determining symbols. Psychological parallelism described by folklore researchers helps to discern symbols in the investigated songs. According to their findings symbol is a lexeme that is the first member of a two-member parallel construction without a second part of the parallel.

As was already mentioned, in this article symbol is also viewed with the number of its meanings and the frequency of its mentioning taken into account. The more important a symbol is, the more often it is mentioned in the songs. This fact allows the ranking of symbols in a descending order of their occurrence. The symbol incidence has been esteemed and the probability of symbol usage calculated. Then the data have been further presented in a tabulated form. Furthermore the numerical data to which a dichotomous method is applied help to discern four groups of symbols. They are conventionally divided into dominant, complementary, auxiliary, and insignificant.

The next stage was devoted to the preparation of diagrams with the ranking of symbols in a descending order of probability. In the summarising diagram each symbol is shown as a separate column with a height proportional to its 
probability of occurrence which is shown in the tables. The columns are arranged in descending order.

There are other approaches and methods of colour analysis in different languages (Davies \& Corbett 1995: 25-36; Corbett \& Davies 1995: 301-357.) But to reveal a list of colour symbols and their semantics, I resorted to my own methods and techniques which were prompted by the material itself.

The investigation into traditional Mari symbolism in folk songs concludes with a summarisation of the results.

\section{RESULTS AND DISCUSSION}

Specific survey findings show that folk songs occupy a particular place in Mari folklore. There are special studies, monographs, and articles dedicated to the classifications of Mari songs, specific features of texts, and musical accompaniment belonging to different sub-ethnic groups. An analytical survey of the ideas is represented in the monograph titled Sistemy simvolov pesen finnougrov Uralo-Povolzh'ia (A System of Symbols in the Songs of Volga-Ural FinnoUgrians) (Glukhov \& Glukhova 2012: 44-48).

Mari songs are divided into two groups: songs connected with different ceremonies and rites (ritual songs) and non-ritual songs. Ritual songs are closely connected with different calendar holidays and family celebrations (wedding songs, remembering songs; lullabies). Non-ritual songs are also numerous. They are 'working' songs, guest songs, orphan's songs, recruit songs, comic songs, love songs, and meditation (contemplation) songs.

The analysis of the subsystem of symbols has been carried out on the material of Mari proper names and folk songs. The article presents the results of investigation of such songs as wedding songs, remembering songs, recruit songs, guest's songs, love songs (mainly), comic songs, and meditation songs without pointing at the genre as the main idea was to show a system of symbols in Mari songs despite their type.

The analysis has shown that in Mari ethnic culture, emotions and feelings are expressed with the help of five leading groups of symbols. Statistical analysis, together with a dichotomous method, reveals the most widespread names of plants, numerals, colours, birds, and animals, organised into groups of complementary, auxiliary, and insignificant symbols, typical of Mari folk songs. The data on each group have been shown in tables and then presented in the form of probability diagrams of names of plants, colours, numerals, birds, and animals mentioned by number in Mari songs. 


\section{Mari system of symbols in songs}

The multifold investigation applied to 2100 songs from different collections of Mari folk songs (Mari kalyk muro 1951; Podelkov 1976; Kulshetov 1990; Vasilyev 1991; Ervel marii muro-vlak 1994; Pesni gornykh mari 2005) allowed to compile a peculiar ranking of symbols mentioned in the analysed texts - names of flora, object colours, numerals, and fauna (Table 1).

Table 1. Ranking of symbols mentioned in Mari folksongs.

\begin{tabular}{|l|l|l|l|}
\hline No. & Type of symbol & $\begin{array}{l}\text { Amount } \\
\text { (number of mentions) }\end{array}$ & Probability \\
\hline 1 & $\begin{array}{l}\text { Plants, trees, flowers, } \\
\text { berries }\end{array}$ & 2966 & 0.432 \\
\hline 2 & Colours of objects & 1554 & 0.226 \\
\hline 3 & Numbers & 882 & 0.128 \\
\hline 4 & Birds & 836 & 0.122 \\
\hline 5 & Animals & 630 & 0.092 \\
\hline Total sums & $\mathbf{6 8 6 8}$ & $\mathbf{1 . 0 0 0}$ \\
\hline
\end{tabular}

The data in the table have been used for drawing a diagram of the probability distribution of symbols mentioned in Mari folk songs. Colour symbols occupy the second place.

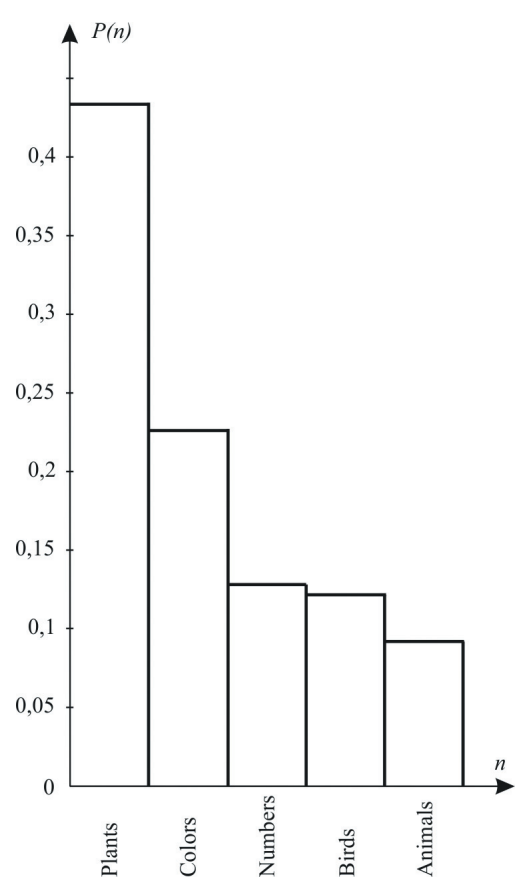

There is no specific research into colour symbolism in Mari songs. This is the first attempt to show the system of colours and their meanings in Mari culture.

The analysed texts present 2000 mentions of four main spectre colours as well as white, black, silver, and golden.

Figure 1. Probability distribution of symbols mentioned in Mari folk songs. 
Statistically, names of colours are distributed in the frequency of their mention and shown in Table 2.

Table 2. Results of the analysis of the number of colour mentions in Mari folk songs.

\begin{tabular}{|c|c|c|c|c|c|c|c|}
\hline No. & Colour & \begin{tabular}{|l|} 
Number of \\
mentions
\end{tabular} & $\begin{array}{l}\text { Probabili- } \\
\text { ty of usage }\end{array}$ & No. & Colour & $\begin{array}{l}\text { Number of } \\
\text { mentions }\end{array}$ & $\begin{array}{l}\text { Probability } \\
\text { of usage }\end{array}$ \\
\hline 1 & White & 448 & 0.288 & 6 & Green & 127 & 0.082 \\
\hline 2 & Black & 276 & 0.178 & 7 & Blue & 83 & 0.053 \\
\hline 3 & Silver & 198 & 0.127 & 8 & Golden & 66 & 0.042 \\
\hline 4 & Yellow & 184 & 0.118 & 9 & Brown & 33 & 0.021 \\
\hline 5 & $\begin{array}{l}\text { Red, pink, } \\
\text { scarlet }\end{array}$ & 127 & 0.082 & 10 & Grey & 12 & 0.008 \\
\hline & & & & \multicolumn{2}{|c|}{ Sums } & 1554 & 1.000 \\
\hline
\end{tabular}

The table shows that dominant colours in the research material are: osh, osho (white), shem, sheme (black) and shii' (silver), as they comprise $59.3 \%$ of all mentions in the investigated songs. Narynche (yellow), yoshkar, yoshkarge (red and its hues), and užarge (green) constitute the next group calculated with the method of consecutive dichotomy (28.2\%). The third and the fourth groups include four colours: kande (blue), shörtn'ö (golden) (12.5\%), küren (brown), and sur (grey) (3\%). Figure 2 presents a diagram drawn on the basis of the data in the table.

A semantic analysis of the songs revealed the meaning of ten colours. The colour names function as epithets in the analysed songs. However, colour characteristics themselves can have their own meanings, which can be seen in the enumerated examples presented in the article.

Here mainly the examples from the dominant group are considered. The most polysemantic colour is white. In Mari old songs there are tautological epithets with this lexeme. It can be seen in the following example:

Pasu gyna pokshelne kugu tumo, In the middle of the field there is a big oak, Kugu tumo jymalne - osh kue. Under the big oak there is a white birch. Kugu tumo, achaem, tin' ulat, The big oak is my father, Osh kuežym parchažym min' ulam And the branches of white birch are me. (Ervel marii muro-vlak 1994: 68)

The adjective osho (white) is associated with a happy life in a big family, together with all relatives (Ervel marii muro-vlak 1994: 23, 61, 67). The word 'white' also expresses the ideas of cleanliness and neatness in the house (Ervel marii muro-vlak 1994: 225). 
The adjective 'white' as an attribute to young girls' clothes shows the naivety of youth and hope of happiness. And yet, life can pass by without realising the cherished dreams.

Osh shavyr chien, parsyn savyc jalshten, In a white linen cloth, in a silk kerchief, Järmingäsh kedeok, ÿdÿr kurymem I did not go to a market place, ertÿsh. but the girlhood slipped by. ...

Osh tygyr chien, jažo zapon pižy̆kten, In a white dress, in a beautiful apron Shÿnzÿshvolkysh läkdeok, ÿdÿr I have never been to the village kurymem ertÿs (Pesni gornykh mari gatherings, but the girlhood slipped by. 2005: 56-57).

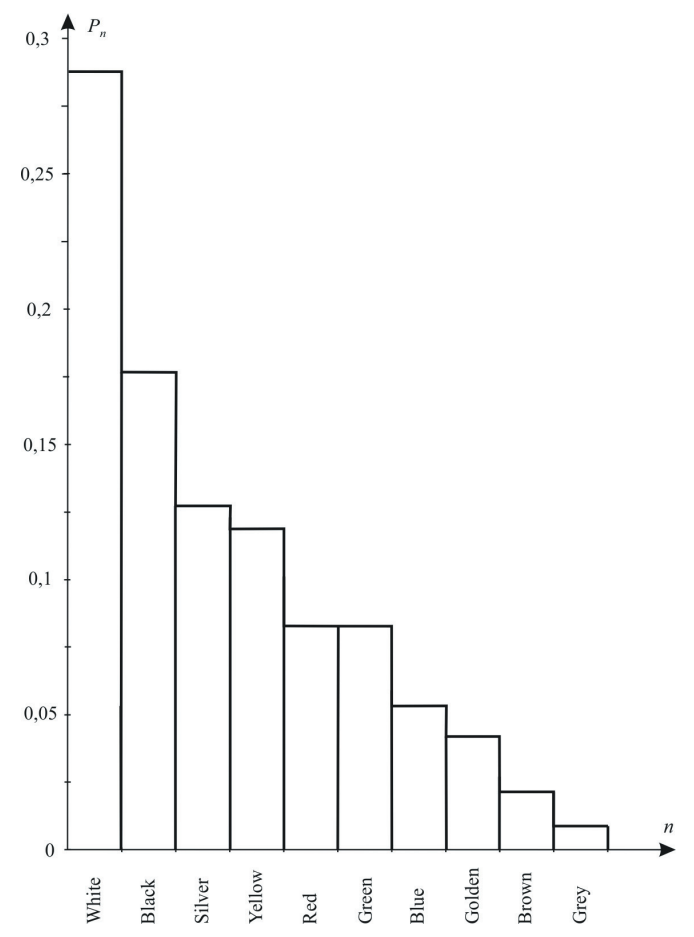

Figure 2. Probability distribution of colours mentioned in Mari songs.

The white colour of a girl's kerchief is associated with her feelings for a young man: 
Osh shovychym osho gynat, Ere mushmem vele shuesh.

Ala, joltashem, syrenat gynat, Ere užmem vele shuesh (Mari kalyk muro 1951: 151).
Though a white kerchief is white I always want to wash it. Though my beloved is cross (with me), I always want to look at him.

In the song Have you climbed up the hill? there is colour antithesis - white vs. black. If white was a symbol of love, the colour black denotes the end of romantic feelings, parting with the young man:

Arka ümbak küzyshych mo?

Shem pyl kaimym užych mo?

Oj, joltashem, syryshych mo?

Vese dene kajymem užych mo?

Myjže pushym osh perchatkym,

Tyjže pushych shememden

Myjže modym chon jöralten

Tyjže modych kudaltash shonen

(Mari kalyk muro 1951: 137-138).
Have you climbed up the hill? Have you seen a black cloud flying by? Oh, my friend, aren't you angry with me? Have you seen that I was walking with another guy?

I have given you the white gloves

You have returned me the black ones.

I loved you with all my heart

And you thought to leave me.

White can express sorrow of the singer coinciding with the meaning of black:

Osh savycym jalshtyshym

Ÿshkežÿ oshy ylamat.

Licäem, oshym, pälevÿ,

Mÿn'ÿn oixem ÿsh pälen.
I put on a white kerchief,

And I was pale myself.

Everybody looked at my pale face,

But nobody learned about my sorrow.

(Pesni gornyh mari 2005: 70).

Black is associated with sorrow, and yearning for a beloved girl:

Jua voktene olykyshtet shüshken

Koshtsho shüshpyk min' yl'ym,

Shem kožlashke purymem godym

Imne kajysh vüd vokten,

Ej! Sagynal'ym tin'ym oilen

(Vasilyev 1991: 89).
Near the River Ya, on the meadow

I was a singing nightingale.

When I entered a dark (lit. black) forest, My horse went along the river.

Oh! And I remembered you with yearning.

The colour black symbolises a strange land and can also be a symbol of danger in communication with distant relatives: 
Shem kožla kornyžym legyldalash

Shishte dech sare-laj imne külesh.

Ty gyna-laj shochshem den ojlasalash

Porsyn dechat pushydi mut külesh

(Ervel marii muro-vlak 1994: 20).
To pass through a black forest you need a light-brown horse, yellower than wax.

To talk with this relative

you need words softer than silk.

Black used to describe girls' eyes is compared to black currants and testifies to their sexual maturity and readiness for marriage.

Kuryk kydalne joshkar isnege

Kuryk laj vujyshto shemshoptyr

Shemshoptyr gane shem shinchat dene

Modyktltyn, memnam savyret.

(Ervel marii muro-vlak 1994: 94).
There are red berries on the hillside;

There is blackcurrant on the hillside.

Flirting with your eyes like

blackcurrant, you are seducing us.

In the following excerpt the idea is the same as in the previous text:

Flashing our black eyes

We give shelter to a handsome man
First we simply give him shelter and then marry him (Podelkov 1976: 98).

Black colour may also characterise beauty of things, clothes, and beloved girl's hair.

Silver is defined as third in frequency in the analysed material. The word shii (silver) in combination with nouns may have the meaning of 'beautiful', 'beloved', 'dear':

Lijdalalže yle shij sambarem, Shinchalalže yle üstembalnem.

Lijdalalže yle yshkemyn joltashem, Shogalalže yle pelenem.

(Kulshetov 1990: 124).
Let the silver samovar be.

Let it stand on my table.

Let me have a dear friend.

Let him always be with me

In some examples, the word silver defining jewellery (rings, earrings, beads) has a direct meaning pointing to a metal of which the jewellery was made, thus emphasising the material prosperity of a person (Ervel marii muro-vlak 1994: 186) or a lost youth.

In the song Aidyza lai udyrlakem (Let us, girls, go out) the combination of the word 'silver' with the noun 'fish' symbolises young girls, fish play - girls' coquettish behaviour. 
Ajdyza laj üdyrlakem

Ajdyza laj üdyrlakem

Vüd türyshkö kaena

Shij kolyn igyžyn

Oj, modmyžym onchena.

Ajdyza laj üdyrlakem

Küshkö ülych küzena.

Küshyl muchashyn üdyrlakyn

Oj, kojyshyshtym onchena.

(Mari kalyk muro 1951: 235)
Let us, girlfriends, go out to

the river bank.

Let us watch

silver fish playing.

Oh, let us watch them playing!

Let us, girlfriends, walk up the street and watch the girls' habits and behaviour there. Oh, let us watch them.

The adjectives 'red', 'pink', 'scarlet' are used in the investigated songs to show joy:

Ojgyren-ojgyrenat, tüsym pytysh, Ajsta shürgesh al chijam jygena.

Shochshyna-laj ukelan jalt jam uke, Ajsta törzash al säs'käm shyndena. (Ervel marii muro-vlak 1994: 133).
I have become pale with grief, Let us paint our faces with pink colour (use pink make-up)

We have no relatives, thus we have nojoy. Let us plant pink flowers on the window sills.

These colours may 'correlate' with youth and beauty (Ervel marii muro-vlak 1994: 62). Pink may be a symbol of mother (ibid.: 281). Yellow and blue with the combination of field flower names are associated with the transiency of youth, beauty of the beloved friend:

Sadvichesh peledesh klovoj vujan peledÿsh,

Klovoj vujan peledÿsh - mloec kurym.
There are blue cornflowers in the garden.

A blue cornflower is a boy's life-time. Alyk lapesh peledesh narynzy vujan peledÿsh, There are yellow flowers in the fields. Narynzy vujan peledÿsh - ÿdÿr kurym. A yellow flower is a girl's life-time. (Pesni gornyh mari 2005: 70-71).

Yellow symbolises melancholy, a yearning to see relatives, grief that leads to early ageing. However, a yellow flower, a yellow ribbon, a yellow kerchief may show the beauty of a beloved girl and relatives. 
Memnan urem ülykö tajyl

Pördyn kaja sar olma.

Tenii kuchymo javyl tangem -

Sajlen nalme sar olma

(Vasiliev 1991: 19).
Our street is sloping down

A yellow apple is rolling easily.

My best friend chosen recently -

Is the best yellow apple of all.

In many Hill Mari songs the yellow colour of a ribbon, kerchief, apron, or shirt symbolises beauty.

Melancholy of a person because of parting with relatives or close friends is shown by the word blue in the analysed songs. The death of a relative is symbolised by a blue flower. Getting old causes sorrow and melancholy; regret regarding the lost youth is also shown with the help of a blue flower. The colour might mean deceit, and it is also associated with orphanhood. In the analysed texts youth and immaturity are expressed by the adjective 'green':

Užar gyna lepen'yn shuldyržo dene Vurgem yshten chijalshe ulo gyn?

Užar gyna vuemym, užar kapemym Ajdemeshat shotlysho ulo gyn?

(Ervel marii muro-vlak 1994: 10).
Who saw clothes made of green butterfly's wings?

Who thinks about me, being so young and inexperienced [lit.: with my green head and green body] seriously?

But the word combination 'green-blue' symbolises the beauty of the world.

The word golden may be used both in direct (description of jewellery) and indirect meanings (description of wealth). It may have the meaning of 'dear' when it concerns parents or native land. It also has the meaning of 'beautiful', 'good'.

A grey duck is a symbol of a beloved girl. To have grey eyes is not very good in a singer's opinion. One should be dark-eyed. When a girl grows up, one should not "look at her with grey eyes": the context shows the meaning of 'with envy' or 'with dislike'. In songs for children the word sur (grey) is used to describe a mouse or a cat.

\section{CONCLUSION}

The history of the study of symbol is very long. Symbol was compared to such literature and arts categories as sign, allegory, personification, artistic image, metaphor, and myth. Scholars write on the correlation of sign and symbol in arts, literature studies, and philosophy, giving different definitions in different schools of semiotics. Symbols, being archaic in their nature, are the most stable elements of culture, which ensures a long-standing interest in their structure and semantics. 
In Mari songs I defined five leading subsystems of symbols. With the help of the rating of subsystems the most frequent group of symbols was found. Colour symbols occupy the second place in the hierarchy of symbols in the analysed songs. Colour symbolism in different cultures as well as the nature of a symbol has a long-lasting history of studies. Nevertheless, colour symbolism on the material of Finno-Ugrians' songs, Mari in particular, has never been the subject of investigation, especially with the described methods and techniques. The conducted research has shown that the triad of dominant colour symbols in Mari song culture embraces white, black, and silver. Their semantics, on the one hand, coincides with the meanings of the objects' colour among other ethnic groups, and, on the other hand, is characterised by certain differences, which are vividly shown by the examples from the analysed songs.

As a result of the analysis of the texts, I have compiled an integrated table, which includes colours of auxiliary and insignificant groups. The table vividly demonstrates the multiple meaning of words - colour denominators in the researched material.

Table 3. Colour symbolism in Mari folk songs.

\begin{tabular}{|l|l|}
\hline \multicolumn{2}{|c|}{ Symbol dominant group of symbols } \\
\hline White & $\begin{array}{l}\text { Life with relatives, happy life in the } \\
\text { family, cleanliness in the house; naivety, } \\
\text { hopes of youth, first love; sorrow; wealth; } \\
\text { beauty; respect }\end{array}$ \\
\hline Black & $\begin{array}{l}\text { Grief; melancholy, foreign country, } \\
\text { strange land; danger; beauty of things, } \\
\text { beauty of the beloved person }\end{array}$ \\
\hline Black currant (description of eyes) & Readiness of young girls to get married \\
\hline Silver & $\begin{array}{l}\text { Beloved friend; beauty; wealth } \\
\text { (possession of silver jewellery) }\end{array}$ \\
\hline \multicolumn{2}{|c|}{ The complementary group of symbols } \\
\hline Red, pink, scarlet & Joy, youth, beauty \\
\hline Yellow & $\begin{array}{l}\text { Melancholy, desire to see relatives; } \\
\text { beauty; joy }\end{array}$ \\
\hline Green & Youth; immaturity \\
\hline \multicolumn{2}{|c|}{ The auxiliary and insignificant groups of symbols } \\
\hline Blue & $\begin{array}{l}\text { Yearning for relatives; melancholy about } \\
\text { the gone youth; death; deceit }\end{array}$ \\
\hline Golden & $\begin{array}{l}\text { Wealth (possession of golden jewellery); } \\
\text { beloved, favourite (about parents, } \\
\text { relatives, native land); beautiful; good }\end{array}$ \\
\hline Brown & Beauty (of things) \\
\hline Grey & Ordinary, not bright, inconspicuous \\
\hline
\end{tabular}


The reconstructed meanings of colour in the analysed Mari folk songs mainly denote emotions (joy, wonder, astonishment, grief, melancholy); some aesthetic ideals (beauty of the beloved); vices (deceit, lies); people's character and appearance. It is interesting to note that white and black may combine with opposite meanings. Along with the description of happiness, white can express coldness in people's relations, discomfort, heavy feelings, and grief. The meaning of black contains both negative connotations that were shown in the examples and the ideal of beauty, bright colours of youth.

\section{REFERENCES}

Averintsev, Sergei 2001. Simvol. [Symbol.] In: Sofiia-Logos: Slovar'. [Sofia-Logos: Slovar'.] Kiev: Duh i Litera, pp. 155-161. Available at http://ec-dejavu.ru/s-2/Symbol.html, last accessed on May 18, 2016.

Berlin, Brent \& Kay, Paul 1991 [1969]. Basic Color Terms: Their Universality and Evolution. Berkeley \& Los Angeles \& Oxford: University of California Press.

Corbett, Greville G. \& Davies, Ian R. L. 1995. Linguistic and Behavioural Measures for Ranking Basic Colour Terms. Studies in Language, Vol. 19, No. 2, pp. 301-357. Available at http://www.ingentaconnect.com/content/jbp/sl/1995/00000019/0000 0002;jsessionid=2ckmtpvp5f276.alice, last accessed on May 18, 2016.

Davies, Ian R. \& Corbett, Greville G. 1994. The Basic Color Terms in Russian. Linguistics, Vol. 32, No. 1, pp. 65-89. http://dx.doi.org/10.1515/ling.1994.32.1.65.

Davies, Ian R. \& Corbett, Greville G. 1995. A Practical Field Method for Identifying Probable Basic Colour Terms. Languages of the World, Vol. 9, No. 1, pp. 25-36. Available at http://epubs.surrey.ac.uk/2090/, last accessed on May 18, 2016.

Deribere, Moris 1964. Tsvet v deiatel'nosti cheloveka. [Colour in Man's Activity.] Translated edition, abridged from French by A. M. Grigoryev.] Moscow: Stroiizdat.

Ervel marii muro-vlak 1994 = Gadiatov, G. (comp.) Ervel marii muro-vlak. Pesni vostochnyh mari. [Songs of the Eastern Maris.] Yoshkar-Ola: Mariiskoye knizhnoye izdatel'stvo.

Frumkina, Revekka 1984. Tsvet, smysl, skhodstvo. [Colour, Meaning, Similarity.] Moscow: Nauka.

Glukhov, Vladimir \& Glukhova, Natalia 2012. Sistemy simvolov pesen finno-ugrov UraloPovolzh'ia. [A System of Symbols in the Songs of Volga-Ural Finno-Ugrians.] Moscow: Spetskniga.

Glukhov, Vladimir \& Glukhova, Natalia 2013. A System of Techniques and Stratagems for Outlining a Traditional Ethnic Identity. In: Frog \& Pauliina Latvala (eds.) Approaching Methodology. Second revised edition with an introduction by Ulrika Wolf-Knuts. Helsinki: Finnish Academy of Science and Letters \& the Finnish Society of Science and Letters, pp. 399-412.

Goethe 1957 = Gete, Iogann. K ucheniiu o tsvete: Khromatika. [On Studying Colour: Chromatics.] Izbrannye sochineniia po estestvoznaniiu. [Selected Works on Natural Science.] Moskva \& Leningrad: Izdatel'stvo AN SSSR, pp. 300-340. 
Kulshetov, D. M. 1990. Shernur kornet: Marii kalyk muro-vlak. [A Sernur Road: Mari Folk Songs.] Yoshkar-Ola: Respublikanskii metodicheskii tsentr kul'tury MASSR.

Losev, Aleksei 1995 [1976]. Problema simvola i realisticheskoe iskusstvo. [The Problem of Symbol and Realistic Art.] Moscow: Iskusstvo. Available at http://www.gumer.info/ bibliotek_Buks/Culture/Los_PrSimv/index.php, last accessed on May 18, 2016.

Lotman, Yuri 1992. Simvol v sisteme kul'tury. [[Symbol in a System of Culture.] Izbrannyie stat'i $v$ tryoh tomah. Tom I: Stat'i po semiotike i topologii kul'tury. [Selected Articles in Three Volumes. Volume I: Articles on Semiotics and Topology of Culture.] Tallinn: Aleksandra, pp. 191-199.

Lotman, Yuri 2000. Semiosfera. [Semiosphere.] Sankt Peterburg: Iskusstvo. Available at https://vk.com/doc6752525_146744970?hash=fc2de899bd0582c6b3\&dl=a0dc1 5b757a75af4fe, last accessed on May 18, 2016.

Mari kalyk muro 1951 = V. Koukal' (comp.) Marii kalyk muro. Mariiskie narodnye pesni. [Mari Folk Songs.] Leningrad \& Moscow: Gosudarstvennoe muzykal'noe izdatel'stvo.

Pesni gornyh mari $2005=$ Pesni gornyh mari. Kyryk mary halyk myryvlä. [Songs of the Hill Maris.] Yoshkar-Ola: Mariiskii nauchno-issledovatel'skii institut iazyka, literatury i istorii im. V. M. Vasil'eva.

Podelkov, Sergei 1976. Mariiskie narodnye pesni. [Mari Folk Songs.] 2nd ed. YoshkarOla: Mariiskoe knizhnoe izdatel'stvo.

Potebnia, Aleksandr 1989. Slovo i mif. [Word and Myth.] Moscow: Pravda.

Ryabina, Elena 2011. Differences in the Distribution of Colour Terms in Colour Space in the Russian, Udmurt and Komi Languages. ESUKA-JEFUL, Vol. 2, No. 2, pp. 191-213. Available at http://jeful.ut.ee/public/files/Ryabina\%20191-213.pdf, last accessed on May 18, 2016.

Sokolov, Yurii 1941. Russkii fol'klor. [Russian Folklore.] Moscow: Gosudarstvennoye uchebno-pedagogicheskoye izdatel'stvo Narkomprosa RSFSR.

Spengler 2000 = Shpengler, Osval'd. Zakat Evropy. [The Decline of the West.] Minsk: Harvest; Moscow: ACT.

Turner, Edith 1997. Anthropology, Symbolic. In: Charlie T. McCormick \& Kim Kennedy White (eds.) Folklore: Encyclopedia of Beliefs, Customs, Tales, Music, and Art. Volume 1. Santa Barbara, CA \& Denver, CO \& Oxford: ABC CLIO, pp. 25-29.

Uliashev, Oleg 1999. Tsvet v predstavleniiakh i fol'klore Komi. [Colour in Conceptions and Komi Folklore.] Syktyvkar: Izdatel'stvo URO RAN.

Uusküla, Mari 2007. The Basic Colour Terms of Finnish. SKY Journal of Linguistics, Vol. 20, pp. 367-397. Available at http://www.linguistics.fi/julkaisut/SKY2007/ UUSKULAo.pdf, last accessed on May 18, 2016.

Uusküla, Mari \& Sutrop, Urmas 2007. Preliminary Study of Basic Colour Terms in Modern Hungarian. Linguistica Uralica, Vol. 43, No. 2, pp. 102-123. Available at http://www.kirj.ee/11171/, last accessed on May 18, 2016.

Vasilyev 1991 = Vasil'ev, V. M. Mariiskie narodnye pesni. [Mari Folk Songs.] YoshkarOla: Mariiskoye knizhnoye izdatel'stvo.

Veselovskii, Aleksandr 1940. Istoricheskaia poetika. [Historical Poetics.] Leningrad: Gosudarstvennoe izdatel'stvo Khudozhestvennaia literatura. Available at https:// vk.com/doc2967709_437463217?hash=216c150d24a9ca157c\&dl=b2ab61387d7bc 821bf, last accessed on May 18, 2016. 
Vezhbitskaia, Anna. 1996. Oboznacheniya tsveta i universalii zritel'nogo vospriyatiya. [Color Designation and Universals of Visual Perception.] In: M. A. Krongauz (ed.) Iazyk. Kul'tura. Poznanie. [Language. Culture. Cognition.] Trans. from English. Moscow: Russkie slovari, pp. 231-291. Available at https://vk.com/doc16897325 5_426866629?hash=9efe5f9d4ee12791ef\&dl=347fb1c2ce232314cf, last accessed on May 18, 2016.

Yanshin 2006 = Ian'shin, Petr. Psikhosemantika tsveta. [Psychosemantics of Colour.] Sankt Peterburg: Rech'. 